\title{
Idalopirdine (LY483518, SGS518, Lu AE 58054) in Alzheimer disease: never change a winning team and do not build exclusively on surrogates. Lessons Learned from Drug Development Trials
}

\author{
Jan M Keppel Hesselink* \\ Department of Molecular Pharmacology, University Witten/Herdecke, Germany
}

Submission: January 11, 2017; Published: February 07, 2017

*Corresponding author: Jan M Keppel Hesselink, Department of Molecular Pharmacology, University Witten/Herdecke, Germany, Email: jan@neuropathie.nu

\begin{abstract}
The effect of Acetylcholinesterase inhibition on Alzheimer's disease is modest. Augmentation strategies are thus whished for and explored. Idalopirdine is a 5HT6 antagonist, and was found to augment the efficacy of acetylcholinesterase inhibitors in animal pharmacology. A phase II study supported the concept, however the study did not follow a dose-finding design, but focused on one dose only, $90 \mathrm{mg} / \mathrm{daily}$. Currently a phase III program further evaluates the value of such augmentation strategy. The first phase III trial however missed the target. This first phase III trial was underdosed; maximum dose was $60 \mathrm{mg} /$ daily, possibly based on an overly firm belief in surrogate parameters, a PET study. We will discuss the phase II and phase III program of idalopirdine in Alzheimer disease and outline the lessons learned for drug development: always use fixed dose range studies in phase II, first define the lowest effective dose and the no-effect dose, as well as the effective dose ( 90 $\mathrm{mg} /$ day). Subsequently do not change the dose-regime from t.i.d. in phase II to once daily in phase III, even if surrogate parameters support such change, neither reduce the dose, in this case from $90 \mathrm{mg}$ daily ( $30 \mathrm{mg}$ t.i.d.) in phase II to $60 \mathrm{mg}$ daily (once daily) in phase III. Follow a conservative drug development pattern and avoid cutting corners seems the lesson of this case of idalopirdine in Alzheimer disease.
\end{abstract}

Keywords: Dose-range; Dementia; Phase III; 5HT6; Antagonism; Serotonin

Abbreviations: FDA: Food and Drug Administration; NMDA: N-methyl-D-aspartate; AChEI: Acetylcholinesterase Inhibitor; CIAS: Impairment Associated with Schizophrenia'

\section{Introduction}

Mid 2016 the U.S. Food and Drug Administration (FDA) granted 'Fast Track Designation' to idalopirdine for the treatment of mild to moderate Alzheimer's disease. [1] Reason to follow this drug in the final phase of her drug development in Alzheimer's disease. Anno 2016 there are at least 24 Alzheimer drugs explored in 36 phase III trials, while 45 agents are explored in 52 phase II trials. [2] Each year thousands of articles are indexed in PubMed when searching for keyword combination Alzheimer's disease and treatment (Figure 1). So far however, only four cholinesterase inhibitors and the $N$-methyl-D-aspartate (NMDA) antagonist, memantine, have obtained marketing approval at an international level [3]. Many drugs failed in the past and sunk in oblivion, such as hydergine, lecitine, choline, metrifonate and nimodipine, while reducing $A \beta$ and tau production was a goal already formulated in the last century, and no disease modifying therapies have been registered yet.

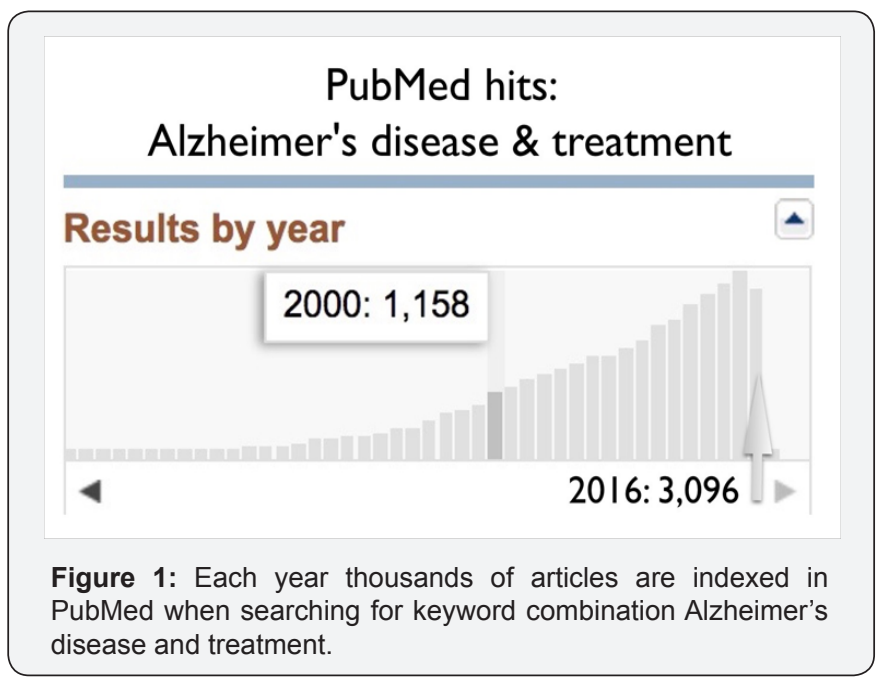


Cholinergic therapy, a kind of substitution therapy, is quite old, and dates from the early 80s. [4] Administered together with the acetylcholinesterase inhibitor (AChEI) donepezil, idalopirdine potentiates the effects of the AChEI on acetylcholine levels in the cortex and hippocampus. [5] From AChEI's we know that the treatment effect is relative modest, and treatment may delay cognitive impairment for a short period of time, like 6 months, while none of the compounds could slow the rate of decline in cognitive or functional capacities over the long term. [6] An augmentation strategy, for instance by adding a 5HT6 antagonist on top of an AChEI might lead to a more pronounced therapeutic effect [7]. Antagonism of the 5-HT6 receptor leads to a comparable effects as acetylcholinesterase inhibition, increasing acetylcholine concentrations in areas such as the frontal cortex and hippocampus, but of course via a different mechanism of action [8]. Such data suggest a role of 5HT6 antagonism in cognitive processes. [9] Furthermore, 5-HT6 receptor blockade enhances glutamatergic, noradrenergic, and dopaminergic neurotransmission. $[10,11]$ The analysis of the role of the 5HT6 receptor system early on was hampered because of the absence of full agonists. First potent and full 5-HT6 agonists synthesized were WAY-181187 and WAY-208466 [12]. Such agonists and partial agonists are now seen as putative antidepressant and anxiolytic compounds $[13,14]$.

\section{Idalopirdine: a 5HT6 antagonist}

Idalopirdine was previously known as SGS518 (Saegis Pharmaceuticals) and Saegis started development in cooperation with Eli Lilly and Company, testing the compound as a treatment for 'Cognitive Impairment Associated with Schizophrenia' (CIAS) [15]. Its first phase I study was completed in 2005. Saegis [16] was later acquired and merged into Lundbeck A/S in December 2006. Lundbeck further designed the clinical program. Idalopirdine was identified in 2002 as a potent antagonist at rat and human 5-HT6 receptors ( $\mathrm{Kb}=19.4,19.1 \mathrm{nM})$. Administration of the compound dose-dependently inhibited in vitro binding of (125I)-SB-258585 to 5-HT6 receptors in rat striatum with an ED50 of $2.2 \mathrm{mg} / \mathrm{kg}$ orally [17]. The 5-HT6 receptor was initially cloned from striatal tissue and has been found mainly in the central nervous system [18]. Compared to other 5-HT receptors, the 5-HT6 receptor is seen as an important therapeutic target for CNS-related pathology, because its expression in the CNS and the fact that there are no known isoforms. [19] Peripheral 5HT6 receptors are believed to play a role in nociception [20].

\section{The clinical program of idalopirdine in Alzheimer's disease: bottlenecks}

In phase I studies idalopirdine has been shown to be safe and well tolerated in doses of up to $360 \mathrm{mg}$ (single dose) [21]. The clinical efficacy program consists of one fixed dose II study, $90 \mathrm{mg}$ idalopirdine/day and 3 phase III studies, evaluating the dose range of 10-60 mg idalopirdine/day, all studies added the compound on top of an ACHEI. In November 24, 2009, a first phase II study was submitted to ClinicalTrials.gov and the study identifier was: NCT01019421, title: 'Randomised, Doubleblind, Parallel-group, Placebo-controlled, Fixed-dose Study of Lu AE58054 in Patients With Moderate Alzheimer's Disease Treated With Donepezil.' The dose tested was $30 \mathrm{mg}$ Lu AE58054 three times daily ( $90 \mathrm{mg} /$ day). The augmentation strategy tested was further explored in 3 phase III studies and one extension study (identifiers: NCT02006641, NCT01955161, NCT02006654, NCT02079246). The dose-range tested in these phases III studies was 10-60 mg once daily. The results of the phase II study NCT01019421 were reported in 2014 [21]. All patients included were stably treated with donepezil $10 \mathrm{mg}$ per day for 3 or more months. Idalopirdine dose selected in the study was $30 \mathrm{mg}$ thrice daily and was based on available non-clinical and human pharmacokinetic data on file at Lundbeck. Included were 133 patients on placebo and 145 on 90 mg Idalopirdine/day.

25 patients withdrew owing to treatment- emergent adverse events, 18 in the idalopirdine group, of which 13 patients had increased (greater than two times the upper limit of normal) aspartate aminotransferase or alanine amino-transferase values, with no concurrent increase in total bilirubin. Eleven of the 13 patients with increased values withdrew from the study. At endpoint, week 24, the change from baseline in ADAS-cog total score was +1.38 (SD 0.53) in the placebo group and - 0.77 (0.55) in the idalopirdine group (treatment difference of -2.16 points, $95 \%$ CI -3.62 to $-0.69 ; \mathrm{p}=0.0040$ ). Secondary endpoints were negative. It is relevant to note, the dose selected in the phase II study was one dose only, and given the failure of the first phase III trials (see under), this stipulates how important it is in drug development to conduct a dose-finding study in phase II! The authors acknowledged this when they brought forward this issue in the discussion: "the use of a single idalopirdine dose means we could not establish whether lower doses would have been efficacious." (p. 1098). Furthermore, it was pointed out that given the narrow MMSE range this phase II study included relatively severely impaired patients, which tend to respond better to interventions [22]. It was also pointed out that idalopirdine is a potent inhibitor of CYP206 and in this trial bioavailability of donepezil increased by $10 \%$.

The phase III efficacy studies defined in clinicaltrials.gov:

\section{I. $\quad$ NCT02006641}

Lu AE58054 in patients with mild-moderate Alzheimer's disease treated with Donepezil (Star beam)

$\mathrm{N}=858$

Dose: Lu AE58054 10 and $30 \mathrm{mg}$, once daily on top of $10 \mathrm{mg}$ Donepezil.

\section{NCT01955161}

Lu AE58054 in patients with mild - moderate Alzheimer's disease treated with Donepezil (Star shine)

$\mathrm{N}=931$ 
Dose: Lu AE58054 $30 \mathrm{mg}$ and $60 \mathrm{mg}$, once daily on top of 10 mg Donepezil

\section{NCT02006654}

Lu AE58054 in patients with mild to moderate Alzheimer's disease treated with an Acetylcholinesterase inhibitor (Star bright)

\section{$\mathrm{N}=734$}

Dose: Lu AE58054 $60 \mathrm{mg}$ or $30 \mathrm{mg}$, once daily on top of an unspecified ACHEI

The results of the first phase III study (NCT01955161), conducted by Lundbeck and its collaborator Otsuka, however failed to support the augmentation strategy, due to most probably under dosing. More than 900 patients with mild-to-moderate Alzheimer's disease were randomized to receive placebo or 30 $\mathrm{mg}$ or $60 \mathrm{mg}$ idalopirdine on top of $10 \mathrm{mg}$ of donepezil. Both doses failed to improve cognition on the Alzheimer's disease Assessment Scale-cognitive subscale and no difference could be detected between placebo and active drug [23]. In the same press release it was stipulated that Lundbeck designed the phase III study program based on a surrogate, using PET, to predict whether the changes to the dose-regimens would affect efficacy. Rates of 5-HT6 receptor occupancy achieved by once-daily 30-mg and 60-mg doses of idalopirdine apparently supported the reduction of daily total dose and simplification of the dose regime from t.i.d. dosing to OD dosing. As the efficacy results of the phase II were modest and perhaps explainable based on the section of a more severely ill cohort or on pharmacokinetic interaction between idalopirdine and donepezil, it seems untimely to explore new leads combining 5HT6 antagonism with ACEI [24].

\section{Conclusion}

The major change between phase II and phase III designs of the drug evaluation program of idalopirdinewas the dose-regime: in phase II there was a thrice-daily $30-\mathrm{mg}$ dosing regime, and this was adapted to once-daily dosing of $30-\mathrm{mg}$ or 60 -mg doses in the first completed Phase III trial. This adaptation was believed to be a response of the company to the tolerability profile of the drug. This deviation from the dose-regime in phase II might have led to a negative phase III study. The case discussed seems to indicate to always use fixed dose range studies in phase II, and first define the lowest effective dose and the no-effect dose. Subsequently do not change the dose-regime from t.i.d. in phase II to once daily in phase III, even if surrogate parameters support such change. Conservatism in drug development might be a key for its success. Furthermore, results from pharmacological in vivo studies are missing; only one study in a rat model of cognitive impairment in schizophrenia was published [25].

\section{References}

1. (2016) Idalopirdine granted Fast Track Designation by U.S. Food and Drug Administration (FDA) Lundbeck press, Denmark.
2. Jeffrey Cummings, Travis Morstorf, Garam Lee (2016) Alzheimer's drug-development pipeline: 2016. Alzheimer's \& Dementia: Translational Research \& Clinical Interventions 2(4): 222-232.

3. Cummings J, Aisen PS, DuBois B, Frölich L, Jack CR, et al. (2016) Drug development in Alzheimer's disease: the path to 2025. Alzheimers Res Ther 8: 39.

4. Summers WK, Viesselman JO, Marsh GM, Candelora K (1981) Use of THA in treatment of Alzheimer-like dementia: pilot study in twelve patients. Biol Psychiatry 16(2): 145-153.

5. Herrik KF, Mørk A, Richard N, Bundgaard C, Bastlund JF, et al. (2016) The 5-HT6 receptor antagonist idalopirdine potentiates the effects of acetylcholinesterase inhibition on neuronal network oscillations and extracellular acetylcholine levels in the rat dorsal hippocampus. Neuropharmacology 107: 351-363.

6. Tayeb HO, Yang HD, Price BH, Tarazi FI (2012) Pharmacotherapies for Alzheimer's disease: beyond cholinesterase inhibitors. Pharmacol Ther 134(1): 8-25.

7. de Bruin NM, Prickaerts J, van Loevezijn A, Venhorst J, de Groote $\mathrm{L}$, et al. (2011) Two novel 5-HT6 receptor antagonists ameliorate scopolamine-induced memory deficits in the object recognition and object location tasks in Wistar rats.

8. Riemer C, Borroni E, Levet-Trafit B, Martin JR, Poli S, et al. (2003) Influence of the 5-HT6 receptor on acetylcholine release in the cortex: pharmacological characterization of 4-(2-bromo-6-pyrrolidin1-ylpyridine-4-sulfonyl) phenylamine, a potent and selective 5-HT6 receptor antagonist. J Med Chem 46(7): 1273-1276.

9. Woolley ML, Marsden CA, Fone KCF (2004) 5-HT6 receptors. Curr Drug Targets CNS Neurol Disord 3(1): 59-79.

10. Dawson LA, Nguyen HQ, Li P (2000) In vivo effects of the 5-HT6 antagonist SB-271046 on striatal and frontal cortex extracellular concentrations of noradrenaline, dopamine, 5-HT, glutamate and aspartate. Br J Pharmacol 130(1): 23-26.

11. Dawson LA, Nguyen HQ, Li P (2001) The 5-HT6 receptor antagonist SB-271046 selectively enhances excitatory neurotransmission in the rat frontal cortex and hippocampus. Neuropsychopharmacology 25(5): 662-668.

12. Schechter LE, Lin Q, Smith DL, Zhang G, Shan Q, et al. (2008) Neuropharmacological profile of novel and selective 5-HT6 receptor agonists: WAY-181187 and WAY-208466. Neuropsychopharmacology 33(6): 1323-1335.

13. Jastrzębska-Więsek M, Siwek A, Partyka A, Szewczyk B, Sowa-Kućma M, et al. (2015) Antidepressant-like activity of EMD 386088, a 5-HT6 receptor partial agonist, following systemic acute and chronic administration to rats. Naunyn Schmiedebergs Arch Pharmacol 388(10): 1079-1088.

14. Jastrzębska-Więsek M, Siwek A, Partyka A, Kubacka M, Mogilski S, et al. (2014) Pharmacological evaluation of the anxiolytic-like effects of EMD 386088, a partial 5-HT6 receptor agonist, in the rat elevated plusmaze and Vogel conflict tests. Neuropharmacology 85: 253-262.

15. PR Newswire (2005) Saegis Pharmaceuticals Completes Phase IIa Clinical Study of SGS518. Saegis Pharmaceuticals Inc, USA.

16. PR Newswire (2005) Saegis Pharmaceuticals Completes Phase I Clinical Study of SGS518. Saegis Pharmaceuticals Inc, USA.

17. Falcone JF, Schaus J, Delapp N, Bauzon D, Thompson D, et al. (2002) The identification of LY483518 as a potent and selective 5-HT6 receptor antagonist. Society for Neuroscience Abstract Viewer \& Itinerary Planner.

18. Monsma Jr FJ, Shen Y, Ward RP, Hamblin MW, Sibley DR (1993) Cloning and expression of a novel serotonin receptor with high affinity for tricyclic psychotropic drugs. Mol Pharmacol 43(3): 320-327. 
19. Yun HM, Rhim H (2011) The serotonin-6 receptor as a novel therapeutic target. Exp Neurobiol 20(4): 159-168.

20. Godínez-Chaparro B, Barragán-Iglesias P, Castañeda-Corral G, RochaGonzález HI, Granados-Soto V. (2011) Role of peripheral 5-HT(4), 5-HT(6), and 5-HT(7) receptors in development and maintenance of secondary mechanical allodynia and hyperalgesia. Pain 152(3): 687697.

21. David Wilkinson, Kristian Windfeld, Eskild Colding-Jørgensen (2014) Safety and efficacy of idalopirdine, a 5-HT6 receptor antagonist, in patients with moderate Alzheimer's disease (LADDER): a randomised, double-blind, placebo-controlled phase 2 trial. The Lancet Neurology 13(11): 1092-1099.

22. Schneider LS (2014) Idalopirdine for Alzheimer's disease: written in the stars. Lancet Neurol 13(11): 1063-1065.

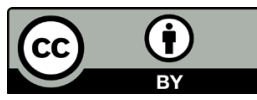

This work is licensed under Creative Commons Attribution 4.0 License

DOI: 10.19080/JPCR.2016.02.555579
23. Nick Paul Taylor (2016) PhIII Alzheimer's flop takes chunk out of Lundbeck, hits Axovant with aftershocks. USA.

24. Więckowska A, Kołaczkowski M, Bucki A, Godyń J, Marcinkowska M, et al (2016) Novel multi-target-directed ligands for Alzheimer's disease: Combining cholinesterase inhibitors and 5-HT6 receptor antagonists. Design, synthesis and biological evaluation. Eur J Med Chem 124: 6381.

25. Arnt J, Bang-Andersen B, Grayson B, Bymaster FP, Cohen MP, et al. (2010) Lu AE58054, a 5-HT6 antagonist, reverses cognitive impairment induced by subchronic phencyclidine in a novel object recognition test in rats. Int J Neuropsychopharmacol 13(8): 1021-1033.

\section{Your next submission with Juniper Publishers will reach you the below assets}

- Quality Editorial service

- Swift Peer Review

- Reprints availability

- E-prints Service

- Manuscript Podcast for convenient understanding

- Global attainment for your research

- Manuscript accessibility in different formats

( Pdf, E-pub, Full Text, Audio)

- Unceasing customer service

Track the below URL for one-step submission https://juniperpublishers.com/online-submission.php 